\title{
Je zasebni najemni sektor v Sloveniji zaželen? Proučitev vloge države pri njegovem razvoju
}

Zasebni najemni sektor (ZNS) v Sloveniji vse od konca druge svetovne vojne deluje brez uradnega priznanja in podpore vladne politike. V članku so proučeni razlogi, zaradi katerih pristojne državne ustanove ta sektor vztrajno zapostavljajo. Avtor v razpravi najprej na kratko pregleda razvoj državne stanovanjske politike, ki je vse od obsežnih stanovanjskih reform v začetku 90. let 20. stoletja globoko zakoreninjena v filozofijo »pristopa omogočanja «. $\mathrm{Na}$ podlagi izsledkov ankete, opravljene med ključnimi državnimi ustanovami, odgovornimi za stanovanjsko oskrbo, je proučena vloga države pri razvoju zasebnega najemnega sektorja po letu 1991, ko je Slovenija uvedla sistem tržnega gospodarstva. Odgovori anketirancev si- cer kažejo, da se proučevane državne ustanove na splošno zavedajo vseh pomanjkljivosti trenutnega zasebnega najemnega sektorja, vendar do zdaj še niso resno podprle njegovega razvoja. Avtor zato sklepa, da lahko dejstvo, da potrebni ukrepi, ki bi podprli razvoj in formalno delovanje zasebnega najemnega sektorja, še niso bili sprejeti, pripišemo nenaklonjenosti oblikovalcev politike do tega sektorja.

Ključne besede: zasebni najemni sektor, struktura pravic do posesti stanovanja, stanovanjska politika, načelo omogočanja, državne ustanove, Slovenija 


\section{Uvod}

Zasebni najemni sektor (v nadaljevanju: ZNS) je kot pomemben segment stanovanjske oskrbe bil in ostaja predmet nenehnih razprav med raziskovalci stanovanjskega področja po vsem svetu. Na voljo je ogromno literature, $v$ kateri različni avtorji obravnavajo različne vidike ZNS (na primer Boelhouwer in van der Heijden, 1992; Malpass in Means, 1993; Forrest in Murie, 1995; McCrone in Stephens, 1995; Balchin, 1996; Boelhouwer in van der Heijden, 1996; Crook in Kemp, 1996). Ob priznavanju njegovih različnih pozitivnih lastnosti prevladuje splošno mnenje, da je ustrezno urejen ZNS nujen, saj ima pomembno vlogo pri vzdrževanju zadostne stanovanjske ponudbe, hkrati pa ponuja alternativo stanovanjskemu lastništvu. Kljub tem pogledom so avtorji v literaturi v splošnem ugotavljali, da je ta sektor $\mathrm{v}$ zadnjih desetletjih nenehno upadal, zaradi česar je v nekaterih državah postal sorazmerno manj pomemben. Nekateri avtorji se strinjajo, da je rezidualizacija ZNS posledica sprememb v stanovanjski politiki, ki je dajala prednost in vse bolj spodbujala lastništvo stanovanj kot bolj zaželeno pravico do posesti stanovanja od najema (glej na primer Harloe, 1985; Ruonavaara, 1990; Forrest in Murie, 1991; Dieleman in Everaers, 1994; Rossi in Weber, 1996; Elsinga in Hoekstra, 2005; Stamso, 2008; De Decker in Dewilde, 2010; Doling in Ronald, 2010; Kleinhans in Elsinga, 2010; Toussaint, 2011). Kljub obdobju splošnega upada je ZNS v zahodnoevropskih državah vedno imel pomembno vlogo in pričakuje se, da bo tako tudi v prihodnje (Gray in McAnulty, 2008; Hulse in Pawson, 2010; Kemp, 2011; Crook in Kemp, 2014). V Veliki Britaniji naj bi se ta sektor po določenem obdobju upada celo povečal (Kemp, 2015). Poleg tega ZNS vse bolj uporabljajo družbene skupine z nižjimi dohodki, ki bi v preteklosti živele v socialnih stanovanjih, vendar se je število teh postopoma zmanjšalo in tako so postala manj dostopna različnim kategorijam gospodinjstev z nizkimi dohodki (Scanlon in Kochan, 2011).

Podrobnejši pregled literature, $\mathrm{v}$ kateri avtorji proučujejo to temo v postsocialističnih državah Srednje in Vzhodne Evrope, kaže, da je bil ta pomembni segment pravic do posesti stanovanja v akademskem diskurzu do zdaj bolj slabo obdelan. Skoraj nihče ni proučeval podrobnosti o naravi in načinu delovanja tega sektorja. Nezadostno posvečanje tej temi lahko opazimo tudi v eni od prvih publikacij o pričakovani tržni usmeritvi stanovanjskega sektorja v Vzhodni Evropi ob prehodu iz planskega v tržno gospodarstvo (Telgarsky in Struyk, 1990). Publikacija je sicer vsebovala poglavje z naslovom »Dodeljevanje stanovanj in pravica do posesti stanovanja «, v katerem je bila ta tema obravnavana za vsako državo, vključeno v raziskavo, kljub temu pa je bil zasebni najemni sektor v njem komaj omenjen. Tudi drugi avtorji (na primer Turner idr., 1992; Struyk, 1996;
Mandič, 2000, Priemus in Mandič, 2000; Donner, 2006) so ZNS v prispevkih o stanovanjskem vprašanju v srednje- in vzhodnoevropskih državah samo na kratko omenili. $\mathrm{V}$ razpravi o Madžarski je bil predstavljen samo splošni pregled sektorja, pri čemer je avtor priznal, da »pravzaprav ni statističnih podatkov o velikosti zasebnega najemnega sektorja « (Erdosi idr., 2000: 272). Za Hrvaško je Sasha Tsenkova (2009: 127) zapisala: »Sektor [ZNS] velja za večjega, vendar v veliki meri deluje v okviru neformalne ekonomije. «Pri obravnavi te teme na Češkem sta Martin Lux in Petr Sunega (2010) razvoj ZNS proučevala le z vidika državnih politik, ki so se izvajale po uvedbi stanovanjskih reform. V nadaljnji raziskavi pa sta Martin Lux in Martina Mikeszova (2012) ugotovila, kako je vračanje prej nacionaliziranega premoženja vplivalo na ZNS in ves češki stanovanjski sistem. Vračanje premoženja je glavna tema obeh omenjenih člankov.

Ker tema do zdaj v Srednji in Vzhodni Evropi še ni bila dovolj raziskana, še ni na voljo empirično podkrepljene in prepričljive razlage, zakaj se postsocialistične države na splošno še naprej ne zmenijo za ZNS. Peter Kemp $(1987,2015)$ v delih na to temo poudarja, da je zasebni najem (kot vse druge pravice do posesti stanovanja) institucija $\mathrm{z}$ razmeroma ustaljenimi značilnostmi, ki veljajo za določeno časovno obdobje. Po njegovem mnenju prav ta dolgotrajnost različnih pravic do posesti stanovanja trgu pomaga, da deluje. »Omogoča, da se stavbe kupujejo in prodajajo ter da jih najemodajalci oddajajo v najem najemnikom pod bolj ali manj natančno določenimi pogoji.« (Kemp, 2015: 603.) Skratka, ZNS ne more ustrezno delovati, če osnovni pogoji, nujno potrebni za njegovo delovanje, niso natančno določeni in vzpostavljeni. Ta trditev je tudi glavna hipoteza tega članka.

Cilj članka je torej proučiti vlogo države pri delovanju ZNS v Sloveniji. Najprej je predstavljen kratek zgodovinski pregled razvoja stanovanjske politike v Sloveniji, pri čemer se kot njen ključni mejnik obravnava sprejetje »načela omogočanja « (uvedenega v okviru stanovanjskih reform leta 1991). Sledi predstavitev trenutnega stanja ZNS in vpliva izvajanja pristopa omogočanja na razvoj tega sektorja. Na tej podlagi so predstavljene in obravnavane ugotovitve ankete, opravljene med ključnimi ustanovami, odgovornimi za stanovanjska vprašanja. V sklepu poskuša avtor pojasniti, zakaj država ni izvedla ukrepov, potrebnih za vzpostavitev osnovnih pogojev za formalno in učinkovito delovanje ZNS.

\section{Razvoj stanovanjske politike}

Za boljše razumevanje bistva problematike, obravnavane $\mathrm{v}$ tem članku, je najprej potreben kratek zgodovinski pregled dogajanja na tem področju $\mathrm{v}$ zadnjih dveh desetletjih, ki je 
ali pa naj bi vplivalo na razvoj ZNS. Slovenija je leta 1991 uvedla sistem tržnega gospodarstva. Šlo je za spremembo, ki so jo (med drugim) spremljale tudi korenite stanovanjske reforme. Ključni ukrepi v okviru teh reform, določeni s stanovanjskim zakonom iz leta 1991, so vključevali odpravo državnega financiranja gradnje novih stanovanj, privatizacijo javnega stanovanjskega fonda in vračilo prej nacionaliziranih stanovanj zakonitim lastnikom. Najvidnejši takojšnji učinek teh reform je bilo seveda močno povišanje deleža lastniških stanovanj (s $67 \%$ pred privatizacijo na $89 \%$ po njej) in posledično občutno zmanjšanje najemnega stanovanjskega fonda. Kmalu za tem je začelo primanjkovati stanovanj (zlasti novih bivališč), kar je bilo neposredna posledica odprave državnega financiranja novogradenj. Vse to je povzročilo stalno rast cen stanovanj od 90. let 20. stoletja do leta 2008 , ko se je začela svetovna finančna kriza in ustavila njihovo nadaljnjo rast.

Prenos odgovornosti države za zagotavljanje stanovanj je bil izveden na podlagi nove mantre $\mathrm{v}$ stanovanjkki politiki, $\mathrm{v}$ tistem času na splošno znane kot »načelo omogočanja «. To načelo je pred tem sprejela Generalna skupščina Združenih narodov in ga je vsem državam po svetu priporočala kot ustrezno strategijo reševanja težav z bivališči (United Nations Centre for Human Settlements, 1988). Kot nakazuje že izraz, je sprejetje »načela omogočanja « pomenilo, da se je vloga države spremenila iz vloge zagotavljanja v vlogo omogočanja. Konkretno je to pomenilo, da naj bi država namesto zagotavljanja stanovanj od takrat naprej ustvarjala pogoje, ki bi njenim državljanom omogočali, da sami zadovolijijo svoje stanovanjske potrebe. Pristop omogočanja so brez oklevanja sprejeli po vsem svetu, po Evropi pa se je intenzivneje izvajal v 90. letih 20. stoletja in tudi pozneje. Vpliv te spremembe v politiki na stanovanjske razmere $\mathrm{v}$ različnih državah je bil obširno obravnavan $\mathrm{v}$ strokovni literaturi (Forrest in Murie, 1990; Kemp, 1991; Cole in Furbey, 1994; Malpass, 1997; Pearl, 1997; Karn in Nyström, 1998; Ridley, 1988; Monk in Whitehead, 2000; Boulhouwer, 2002; de Decker, 2002; Kristensen, 2002; Matznetter, 2002; Pareja Eastaway in Varo, 2002; Priemus in Dieleman, 2002; Turner in Whitehead, 2002; Gruis idr., 2009).

Ko je bil v Sloveniji sprejet dokument o nacionalni stanovanjski politiki ( $v$ nadaljevanju: NSP), je bilo v njem »načelo omogočanja « opredeljeno kot sodoben pristop, ki naj bi zamenjal zastarelo doktrino zagotavljanja stanovanj. Dokument je določal, da je glavni cilj načela doseči »debirokratizacijo stanovanjskega področja in zamenjavo administrativnega dodeljevanja stanovanj s postopki za organiziranje stanovanjskega tržišča ter s podporo zasebnim pobudam « (Nacionalni stanovanjski program, Ur. l. RS, št. 43/2000: 5771) ${ }^{[1]}$. Od takrat naprej naj bi država zagotavljala pomoč v obliki različnih ugodnosti, in sicer samo tistim skupinam državljanov, ki finančno ali kako drugače ne bi bili zmožni sami rešiti svojega stanovanjskega vprašanja (skupine z najnižjimi dohodki in določene ranljive skupine).

Med številnimi cilji, določenimi v NSP, se na razvoj ZNS neposredno nanašajo ti:

- oblikovati partnerstva med javnim in zasebnim sektorjem;

- zagotoviti pravni in organizacijski okvir za usklajeno delovanje vseh akterjev na stanovanjskem področju;

- uravnotežiti ponudbo in povpraševanje po stanovanjih tako, da bo zagotovljeno zadostno število stanovanj, namenjenih za nakup ali pridobitev v najem, tam, kjer obstaja primanjkljaj ali povpraševanje po stanovanjih;

- spodbujati delovanje stanovanjskega trga in njegovih pozitivnih učinkov na družbeni in gospodarski razvoj.

V kratkem opisu teh ciljev je bilo navedeno, da zaradi stalnega velikega povpraševanja po najemnih stanovanjih, zlasti $\mathrm{v}$ velikih mestih in regionalnih središčih, obstaja potreba po tem, da del potrošnikov svoje stanovanjske potrebe zadovolji $s$ pomočjo zasebnega najemnega sektorja. Te potrebe bi bile zadovoljene samo, če bi bili vzpostavljeni taki tržni pogoji, ki bi potencialnim najemodajalcem zagotavljali ustrezno donosnost naložbe. Dokument je poleg tega določal, da je treba zagotoviti minimalno zaščito zasebnih najemnih pogodb, ki bi najemnikom zagotavljale pravico do posesti stanovanja, hkrati pa najemodajalcev ne bi odvračale od tega, da svoje nepremičnine ponudijo na najemnem trgu. Končni cilj je bil postopoma razširiti zasebne naložbe (ki so bile v tistem času skoraj izključno usmerjene v pridobitev lastniškega stanovanja) tudi na naložbe v stanovanja za oddajo v najem.

V skladu z NSP naj bi država po novem imela dvojno vlogo: 1. $\mathrm{Z}$ uporabo ustreznih ukrepov naj bi vplivala na denarne trge za zagotavljanje posojil za stanovanjsko gradnjo. Ta poseg na nepremičninskem trgu bi spodbudil konkurenčnost in izboljšal razmere na trgu, kar bi povečalo ponudbo in zmanjšalo povpraševanje. $Z$ davčnimi spodbudami, zlasti v povezavi z obdavčitvijo nepremičnin, bi država postopno zagotovila racionalnejšo izrabo obstoječega stanovanjskega fonda.

2. Država in lokalne skupnosti naj bi spodbujale zlasti gradnjo, prenovo in nakupe najemnih neprofitnih in socialnih stanovanj. Poleg tega bi bile zagotovljene spodbude za mobilizacijo prihrankov prebivalstva, kar bi omogočilo naložbe v zasebni najemni sektor in hkrati spodbudilo tudi pridobivanje lastniških stanovanj.

Izvajanje zgoraj opisanih ukrepov v okviru pristopa omogočanja bi moralo pripeljati do razvoja alternativnih stanovanjskih možnosti (Mandič in Filipovič Hrast, 2015) ter do oblikovanja ustrezne podlage za formalno delovanje in postopen razvoj 
ZNS. Podrobna analiza dosežkov izvajanja NSP, opravljena leta 2007 (17 let po uvedbi stanovanjskih reform), pa je pokazala, da ni bil uresničen skoraj noben cilj NSP (Sendi, 2007). V naslednjem poglavju so predstavljena dejstva, ki dokazujejo, da cilji, povezani s ZNS, nikakor niso bili doseženi.

\section{Trenutno stanje ZNS v Sloveniji}

Medtem ko je izvajanje stanovanjskih reform na splošno močno vplivalo na ponudbo in cene stanovanj, je težko natančno oceniti vpliv te spremembe $\mathrm{v}$ politiki na ZNS. Vzrok za to izhaja iz dejstva, da ob uvedbi stanovanjskih reform ZNS v Sloveniji sploh ni obstajal (če sklepamo po uradnih statističnih podatkih). Po drugi svetovni vojni statistični podatki o pravicah do posesti stanovanja nikoli niso vključevali podatkov o najemnih stanovanjih v zasebni lasti. Do leta 1994 so se objavljali samo podatki za stanovanja v lasti javnega ali zasebnega sektorja, leta 1995 pa sta bili ti kategoriji spremenjeni v kategoriji »pravna oseba « in »fizična oseba «. Tak način predstavljanja podatkov o lastništvu stanovanj je bil še bolj problematičen. Oznaka »fizična oseba « se lahko nanaša na zasebno/individualno lastništvo, medtem ko se izraz »pravna oseba « dejansko lahko nanaša na večje oziroma institucionalne investitorje tako iz zasebnega kot javnega sektorja, ki imajo običajno status pravne osebe. Ne samo, da ni bilo na voljo nobenih podatkov o fondu najemnih stanovanj v zasebni lasti, ampak tudi iz uradnih statističnih podatkov ni bilo razvidno, kakšen je bil delež javnih stanovanj in kakšen je bil delež stanovanj v lasti zasebnih institucionalnih investitorjev. Avtor meni, da je bila dvoumna oblika predstavljanja tovrstnih podatkov lahko uporabljena namenoma, da bi se prikril dejanski (izjemno nizek) delež stanovanj v javni lasti.

Čeprav podatki o tej pravici do posesti stanovanja niso bili objavljeni, je vedno na splošno veljalo, da ZNS obstaja. Storitev je bila na voljo še pred uvedbo tržnega gospodarstva, komunistični režim jo je tiho dopuščal, namenjena pa je bila tistim, ki svojih stanovanjskih potreb niso mogli kako drugače zadovoljiti (Sendi, 1995, 1999). Podatki o velikosti tega sektorja se presenetljivo niso objavljali niti po uvedbi tržnega gospodarstva in stanovanjskih reform, ki naj bi med drugim spodbudile tudi razvoj ZNS. Ob objavi rezultatov državnega popisa leta 2012 je Statistični urad Republike Slovenije (v nadaljevanju: SURS) v poročilu navedel te podatke: skupno 844.656 bivališ̌c, od teh jih je $761.300(90 \%)$ v lasti fizičnih oseb, 47.348 (6\%) v lasti javnega sektorja in 27.798 (3\%) v lasti drugih pravnih oseb, 8.210 (1\%) pa jih je bilo uvrščenih v kategorijo službenih najemnih stanovanj (SURS, 2012). To prvotno poročilo je sicer razlikovalo med javnim sektorjem in drugimi pravnimi osebami, vendar ni vsebovalo podatkov o velikosti ZNS.
Preglednica 1: Struktura pravic do posesti stanovanja v fondu zasedenih stanovanj

\begin{tabular}{lll}
\hline pravica do posesti stanovanja & število bivališč & delež (\%) \\
\hline lastniško zasedena stanovanja & 523.070 & 78,06 \\
\hline stanovanja brez najemnine & 84.905 & 12,67 \\
\hline najemna stanovanja & 62.152 & 9,27 \\
\hline neprofitna stanovanja & 43.438 & 6,48 \\
\hline tržna stanovanja & 12.378 & 1,85 \\
\hline $\begin{array}{l}\text { službena najemna stanovanja } \\
\text { institucionalna stanovanja (starej- } \\
\text { ši, študenti itd.) }\end{array}$ & 4.405 & 0,66 \\
\hline $\begin{array}{ll}\text { skupaj fond zasedenih stanovanj* } \\
\text { * }\end{array}$ & 670.127 & 0,29 \\
\hline
\end{tabular}

Opomba: *Skupaj fond zasedenih stanovanj = lastniško zasedena stanovanja + stanovanja brez najemnine + najemna stanovanja.

Vir: SURS (2013)

Do pomembnega mejnika na tem področju je prišlo čez leto dni, ko je bilo objarljeno podrobnejše poročilo. SURS je končno upošteval dolgoletne zahteve raziskovalcev in tako objavil tudi podatke o fondu najemnih stanovanj v zasebni lasti. Od ustanovitve SURS leta 1944 so bili tovrstni podatki prvič objavljeni, uradno pa so bili uvrščeni v kategorijo »tržna stanovanja $\ll$ (preglednica 1$)$.

Iz preglednice 1 je razvidno, da je delež zasebnih najemnih stanovanj v celotnem fondu zasedenih stanovanj znašal 1,9\%. Nihče v državi pravzaprav ne ve, kako velik je ZNS v resnici, vendar se strokovnjaki s stanovanjskega področja na splošno strinjajo, da ta številka ni pravilna. Ker uradna državna politika ta sektor vztrajno zanemarja, večinoma deluje nezakonito (to je brez uradne prijave). Delež, prikazan v preglednici 1, ponazarja samo zasebne najeme, ki so bili v času popisa prijavljeni pri pristojnih lokalnih organih. Avtor meni, da je dejanski delež ZNS veliko višji, in uradno objavljeni delež izpodbija na podlagi dveh podatkov iz popisa iz leta 2011. Prvič, v popisu je bilo ugotovljeno, da je $21 \%$ celotnega stanovanjskega fonda nezasedenega oziroma praznega, in drugič, $13 \%$ zasedenega fonda je bilo uvrščeno med stanovanja, za katera se ne plačuje najemnina. SURS tovrstna stanovanja opredeljuje kot stanovanja, $\mathrm{v}$ katerih živijo osebe, ki niso lastniki stanovanja, vendar zanj ne plačujejo najemnine (sorodniki, prijatelji in podobno). V obeh primerih je zelo verjetno, da se določen delež » praznih « stanovanj in stanovanj » brez najemnine « pravzaprav oddaja na zasebnem najemnem trgu. Problem pa je, da na podlagi metode, ki jo SURS uporablja za zbiranje podatkov v okviru popisa, ne moremo preveriti dejanske uporabe stanovanj ali vrste pravice do posesti stanovanja. Čeprav stanovanja brez najemnine obstajajo tudi v nekaterih drugih državah (glej na primer Scanlon in Kochan, 2011, za ZDA ter Crook in Kemp, 2014, za Španijo), v Sloveniji izstopa dejstvo, da taka stanovan- 
ja predstavljajo $58 \%$ vsega fonda stanovanj, v katerih ne živijo lastniki. Čeprav še vedno ni na voljo zanesljivega vira natančnih podatkov o pravi naravi kategorij »praznih « stanovanj in stanovanj »brez najemnine « v Sloveniji, se vsi strokovnjaki s stanovanjskega področja na splošno strinjajo, da se določen delež tega fonda oddaja na sivem trgu. Kot sta ugotovila Hugo Priemus in Srna Mandič (2000), naj bi bil trenutni slovenski ZNS le podaljšek sektorja lastniško zasedenih stanovanj.

\section{Proučitev vloge države}

Raziskava vzrokov, zaradi katerih državne ustanove, pristojne za stanovanjsko oskrbo, vztrajno zanemarjajo ZNS, se je osredotočala na proučevanje njihov stališč glede obstoja in pomena tega sektorja. Poudarek je bil na iskanju odgovorov na ta ključna vprašanja:

1. Ali ključne državne ustanove priznavajo pomen in potencialno vlogo ZNS?

2. Kakšne zadržke ali pomisleke imajo te ustanove (če sploh) glede obstoja in uspešnega delovanja ZNS?

3. Kaj menijo o trenutnih okoliščnah, v katerih država še naprej zanemarja ZNS?

4. Katere nujne ukrepe predlagajo (če so naklonjene obstoju tega sektorja) za uspešen razvoj in delovanje ZNS?

\subsection{Metode}

Ker je bila raziskava usmerjena v izbrane državne ustanove, je bila uporabljena metoda namenskega vzorčenja. Avtor je najprej naredil seznam javnih ustanov, ki jih je želel proučiti, nato pa je sestavil več vprašalnikov za samoizpolnjevanje, ki so vsebovali ustrezna vprašanja za vsako posamezno ustanovo. Glede na naravo ankete je šlo za strukturirane vprašalnike $\mathrm{z}$ vprašanji odprtega tipa, katerih namen je bil čim bolj raziskati stališča, poglede in dejavnosti proučevanih ustanov.

Vprašalniki so bili najprej poslani po pošti, na zahtevo sodelujočih ustanov pa so bili na voljo tudi v elektronski različici. V anketo so bile vključene te glavne javne ustanove:

1. ključna ministrstva:

- ministrstvo za infrastrukturo in prostor (neposredno odgovorno za stanovanjska vprašanja);

- ministrstvo za finance;

2. vse politične stranke $\mathrm{v}$ takratnem državnem zboru, skupaj $s$ pristojnim parlamentarnim odborom (Odbor državnega zbora za infrastrukturo in prostor); ${ }^{[2]}$

3. Stanovanjski sklad Republike Slovenije (paradržavni organ, odgovoren za izvajanje nacionalne stanovanjske politike).

Vprašalnike so izpolnile vse ustanove, vključene $\mathrm{v}$ anketo, razen treh parlamentarnih strank. Vprašanja so se glede na posame- zno ustanovo razlikovala, vseeno pa so tri sestavljala jedro raziskave. Eno od vprašanj je bilo poslano samo parlamentarnim strankam. Anketna vprašanja so predstavljena v nadaljevanju.

1. Vprašanje 1

Podatki popisa, objavljeni leta 2012, kažejo, da:

- je $90 \%$ (761.300) stanovanj v lasti fizičnih oseb;

- je $6 \%$ (47.348) stanovanj v lasti javnega sektorja;

- je $3 \%$ (27.798) stanovanj v lasti drugih pravnih oseb;

- je $1 \%$ (8.210) stanovanj uvrščenih v kategorijo »lastnik neznan «.

(a) Kako komentirate te podatke? Kaj menite o deležu stanovanj v lasti fizičnih oseb $(90 \%)$ ? Je ustrezen, previsok ali prenizek?

(b) Kaj menite o tovrstnem načinu predstavljanja statističnih podatkov, ki ne vključuje podatkov o številu (ali deležu) stanovanj, ki se oddajajo na zasebnem trgu ${ }^{[3]}$

\section{Vprašanje 2}

Podatki popisa, objavljeni leta 2012, kažejo, da je »do $175.000(20,7 \%)$ bivališč praznih «.

a) Kaj menite o podatku, da je petina celotnega stanovanjskega fonda prazna?

b) Bi bilo treba v tej povezavi sprejeti kakršne koli davčne ukrepe?

c) Če ja, katere?

\section{Vprašanje 3}

a) Ali (ime ustanove) meni, da je ZNS potreben? Če ja, zakaj?

b) Če menite, da je ZNS potreben, ali se strinjate, da bi morali učinkovito delovanje tega sektorja zagotoviti tudi z ustrezno vladno finančno podporo? Če ja, kakšno obliko finančne podpore predlagate (na primer subvencije, davčne olajšave ipd.)?

c) Kakšno je stališč (ime ustanove) glede trenutne ponudbe zasebnih najemnih stanovanj in trenutnega načina delovanja ZNS?

4. Vprašanje 4 (poslano samo parlamentarnim strankam) Je (ime parlamentarne stranke) kadar koli obravnavala stanje ZNS in način njegovega delovanja v Sloveniji?

a) Če ja, kaj natančno je obravnavala? Ste na tem področju opazili kakšne težave? Katere so bile te in kakšni so bili sklepi razprave parlamentarne stranke?

b) Ali predlagate kakšne konkretne ukrepe za ureditev dejavnosti ali delovanja zasebnega najemnega sektorja? Navedite konkretne ukrepe, ki se nanašajo na:

1. pravno ureditev (pravice najemnikov in lastnikov itd.),

2. obdavčitev,

3. financiranje,

4. najemno politiko,

5. drugo. 


\section{Rezultati ankete in razprava}

Razprava o odgovorih anketiranih ustanov se osredotoča na te ključne vidike raziskave:

- trenutno strukturo pravic do posesti stanovanja in način predstavljanja podatkov,

- prazna bivališča in ukrepe za reševanje tega problema,

- trenutno ponudbo in način delovanja ZNS,

- potrebo po učinkovitem ZNS in

- vlogo državnega zakonodajnega organa.

Prva splošna ugotovitev, povezana $\mathrm{z}$ rezultati ankete, je, da anketirane ustanove niso vedno popolnoma odgovorile na zastavljena vprašanja. Poleg tega so bili nekateri odgovori nejasni, nepomembni ali dvoumni.

\subsection{Trenutna struktura pravic do posesti stanovanja in način predstavljanja podatkov}

Parlamentarni odbor za infrastrukturo in prostor se je strinjal, da je delež stanovanj v lasti fizičnih oseb previsok, vendar so bili njegovi odgovori dvoumni. Po eni strani je dvomil, da bi gospodinjstva lahko pokrila stroške najema, s čimer je posredno nakazal, da verjetno ni velike potrebe po zasebnih najemnih stanovanjih. Po drugi strani pa se je zavedal finančnih stisk lastnikov stanovanj, ki jih bremenijo hipotekarne obveznosti. $\mathrm{Na}$ koncu odbor ni podal jasnega končnega mnenja glede trenutne strukture pravic do posesti stanovanja.

Da je delež lastniških stanovanj previsok, se je strinjalo tudi ministrstvo za infrastrukturo in prostor. V odgovoru na vprašanje o natančnih podatkih o pravicah do posesti stanovanja, ki je bilo ločeno zastavljeno prav temu ministrstvu, so pogumno zatrdili, da imajo »grobo oceno « podatkov o velikosti fonda najemnih stanovanj v zasebni lasti. Nato pa so navedli isto številko, kot jo je objavil SURS: 12.387 bivališč (kot je prikazano v preglednici 1). To dokazuje, da ministrstvo, neposredno odgovorno za oblikovanje stanovanjske politike, nima niti natančnih podatkov niti grobe ocene o dejanski velikosti ZNS. Dejstvo, da to ministrstvo nima navedenih podatkov, neizogibno pomeni, da ni zmožno oblikovati primerne politike na tem področju.

Da je delež lastniških stanovanj previsok, sta menila tudi parlamentarna stranka 2 in ministrstvo za finance. Glede strukture pravic do posesti stanovanja so pri Stanovanjskem skladu Republike Slovenije izjavili, da so trenutne okoliščine posledica prejšnjega (socialističnega) političnega sistema in njegove stanovanjske politike. Razložili so tudi, da želi večina Slovencev imeti dom ali stanovanje v svoji lasti, da je kratkotrajni najem samo začasna rešitev in da je dolgoročni najem na zasebnem trgu v Sloveniji redek. Avtor se vsekakor strinja $s$ trditvijo glede vsesplošne slovenske obsedenosti z željo po lastnem stanovanju, ne strinja pa se popolnoma $\mathrm{z}$ argumentom, da je trenutna struktura pravic do posesti stanovanja posledica prejšnjega komunističnega sistema. Glede na to, da so lastnišska stanovanja ob koncu komunističnega režima tvorila $67 \%$ celotnega stanovanjskega fonda, podatek, da se je njihov delež do popisa leta 2011 povečal na $90 \%$, kaže, da je morala biti tudi vladna politika, ki se je izvajala po uvedbi sistema tržnega gospodarstva, naklonjena nadaljnji gradnji in rasti tovrstnih stanovanj. Privatizacija nekdanjega javnega stanovanjskega fonda in različni programi stanovanjskega subvencioniranja (vsi ukrepi so bili izvedeni po uvedbi tržnega gospodarstva) so občutno pripomogli k povečanju števila lastniških stanovanj. Res je, da imajo lahko državljani najrazličnejše osebne cilje, vendar ima država vedno moč, da ureja in nadzira dogodke, še zlasti tiste, ki vplivajo na državno gospodarstvo in splošno blaginjo prebivalstva. Glavni avtorjev argument v zvezi s tem je, da državi ni uspelo zagotoviti pogojev (ali pa tega namerno ni storila), ki bi omogočili razvoj alternativnih pravic do posesti stanovanja, kot je najem zasebnega stanovanja.

Odgovor parlamentarne stranke 4 na isto vprašanje je bil natančnejši in se je ujemal $z$ avtorjevim mnenjem, saj so za trenutno strukturo pravice do posesti stanovanja neposredno okrivili vladno politiko, ki se je izvajala po osamosvojitvi Slovenije. Podobno je tudi parlamentarna stranka 3 omenila vlogo državne stanovanjske politike, pri čemer je poudarila vpliv, ki ga je politika, osredotočena na povpraševanje, imela na povišanje cen stanovanj, kar je mladim iskalcem stanovanj otežilo dostop do stanovanjskega trga. Tudi parlamentarna stranka 4 je izjavila, da je glavni problem, povezan s trenutnim stanjem ZNS, da ta sektor upravlja neurejen nepremičninski trg, hkrati pa ga ureja neustrezna davčna politika.

Kot ministrstvo za finance je tudi parlamentarna stranka 3 poudarila neustreznost metode zbiranja podatkov na državni ravni in neizvajanje učinkovitega tržnega nadzora. $\mathrm{V}$ zvezi s tem se je parlamentarna stranka 1 strinjala, da trenutna metodologija zbiranja podatkov in način njihove predstavitve ne izražata resničnega stanja glede pravic do posesti stanovanja $\mathrm{v}$ državi.

Če povzamemo, so se vse proučevane ustanove tako ali drugače strinjale, da je delež lastniških stanovanj previsok, delež najemnih stanovanj pa prenizek. Podobno se vsi anketiranci zavedajo pomanjkljivosti trenutnega načina zbiranja in predstavljanja podatkov o pravicah do posesti stanovanja. Vsi menijo, da bi bilo treba podatke o strukturi pravic do posesti stanovanja zbirati in predstaviti tako, da bi bilo mogoče prepoznati in objaviti tudi podatke o ZNS. 


\subsection{Prazna stanovanja in ukrepi za reševanje tega problema}

Parlamentarni odbor za infrastrukturo in prostor je na vprašanje o praznih stanovanjih odgovoril tako: »Po našem mnenju bi morala biti prazna stanovanja obdavčena.« Tak odgovor izraža »ne ravno zaskrbljujoč « odnos ene od ključnih državnih ustanov do te pomembne hibe stanovanjskega trga. Ministrstvo za finance je ponudilo podrobnejši odgovor na to vprašanje. Njihovo glavno stališče je bilo, da so prazna stanovanja drugotnega pomena z vidika obdavčitve nepremičnin, saj ne vplivajo na davčno osnovo. Priznali pa so, da bi bilo treba doseči racionalno uporabo obstoječega stanovanjskega fonda, in $\mathrm{v}$ ta namen predlagali uvedbo posebnih davčnih ukrepov. Ti mnenji potrjujeta, da ministrstvo za finance obdavčitev na tem področju pojmuje kot orodje za boj proti praznim stanovanjem in ne kot mehanizem za zbiranje prihodkov v državni proračun. Po eni strani gre za hvalevredno stališče, po drugi pa ga lahko razumemo kot eno od razlag za pasivnost vlade na tem področju, glede na to, da ministrstvo, pristojno za fiskalno politiko, ne predvideva nobenih gospodarskih koristi za državni proračun iz obdavčitve praznih stanovanj.

Po mnenju parlamentarne stranke 1 je delež praznih stanovanj previsok, pri čemer bi se moral ta problem nujno reševati $z$ uvedbo ustreznih spodbud, namenjenih zapolnitvi praznih stanovanj. Podobno je tudi parlamentarna stranka 2 menila, da bi bilo treba sprejeti ugodnejšo davčno politiko, na podlagi katere bi bila prazna stanovanja čim prej na voljo na najemnem trgu. $\mathrm{V}$ nasprotju s predlogom ministrstva za finance je parlamentarna stranka 2 podvomila v primernost potencialne obdavčitve praznih stanovanj in kot alternativo predlagala davčno olajšavo za zasebne lastnike (za določeno začetno obdobje), ki bi odpravila enega od največjih razlogov za nezakonito opravljanje te dejavnosti (to je visoko davčno stopnjo). $S$ tem se je strinjala tudi parlamentarna stranka 4, ki je predlagala, da bi morali z nižjimi davki na dohodek od najemnin zasebne investitorje spodbuditi $\mathrm{k}$ temu, da svoja prazna stanovanja ponudijo na najemnem trgu. Podobno je bila tudi parlamentarna stranka 3 naklonjena davčni politiki, ki bi bolj podprla ZNS. Po njenem mnenju bi bila večina najemodajalcev pripravljena skleniti dolgoročnejše najemne pogodbe (čeprav pri tem ni navedla dokazov, ki bi podprli to domnevo), če bi predpisi omogočali prekinitev pogodbe v upravičenih primerih. Poleg davčnih ukrepov sta parlamentarni stranki 1 in 2 predlagali tudi uvedbo ukrepov za okrepitev nadzora nad delovanjem ZNS.

Odgovori, predstavljeni v tem delu, kažejo, da po mnenju vseh anketiranih ustanov tako veliko število praznih stanovanj ni primerno. Za reševanje tega problema sta bila predstavljena dva predloga za spremembo politike. Parlamentarni odbor za infrastrukturo in prostor in ministrstvo za finance vidita rešitev $\mathrm{v}$ obdavčitvi praznih stanovanj, parlamentarne stranke pa so na splošno bolj naklonjene uvedbi ugodnejše davčne politike, ki bi imela spodbuden vpliv na zasebne investitorje.

\subsection{Trenutna ponudba in način delovanja ZNS}

Parlamentarni odbor za infrastrukturo in prostor je na to vprašanje preprosto odgovoril: »Nismo seznanjeni s situacijo. « Če je to iskren odgovor (in ni razloga, da ne bi bil), kar veliko pove o resnosti zakonodajnega organa, katerega glavna naloga je, da obravnava ukrepe stanovanjske politike in jih predlaga parlamentu. Odgovor jasno kaže odnos zadevnega odbora do ZNS in lahko pomaga pojasniti razloge za trenutno stanje ZNS.

Ministrstvo za infrastrukturo in prostor meni, da je trenutno stanje ZNS » problematično zaradi velikega števila stanovanj, ki naj bi se domnevno nezakonito oddajala v najem «. Z uporabo besede »domnevno « je ministrstvo, neposredno pristojno za stanovanjska vprašanja, v bistvu (spet) priznalo, da nima natančnih podatkov o dejanskem obsegu najemne dejavnosti na zasebnem trgu. Je pa kot enega od glavnih problemov, povezanih $s$ trenutnim ZNS, omenilo trajanje sodnih postopkov $\mathrm{v}$ sporih v zvezi z najemnimi razmerji, ki v povprečju trajajo tri leta, lahko pa mine tudi več kot pet let, preden se končajo.

Parlamentarna stranka 1 je v odgovoru na to vprašanje opozorila na nepreglednost delovanja ZNS, ki po njenem mnenju vodi v zlorabe in sivo ekonomijo. Glede neustrezne trenutne ponudbe zasebnih najemnih stanovanj je parlamentarna stranka $2 \mathrm{v}$ odgovoru pojasnila, da je tako stanje med drugim posledica tega, da najemodajalci ne želijo tvegati in svojega stanovanja oddati najemnikom, ki ne bi redno plačevali najemnine. Podobno kot ministrstvo za infrastrukturo in prostor je veliko oviro za učinkovito delovanje ZNS videla v dolgotrajnih sodnih postopkih v primeru sporov. To bi bilo dejansko lahko res. Avtor članka se strinja, da so poleg visoke stopnje obdavčitve dolgotrajni sodni postopki pomemben dejavnik, ki nespodbudno vpliva na potencialne investitorje $\mathrm{v}$ ta sektor.

Iz odgovorov, podanih $\mathrm{v}$ tem delu, lahko strnemo tri glavne ugotovitve. Proučevane ustanove nimajo natančnih podatkov o obsegu dejavnosti na zasebnem najemnem trgu, vse pa se zavedajo, da ZNS obstaja in da deluje nezakonito. Večina se tudi strinja, da so dolgotrajni sodni postopki reševanja sporov med najemodajalci in najemniki pomemben odvračajoč dejavnik, ki ovira uspešno delovanje ZNS.

\subsection{Potreba po učinkovitem ZNS}

$\mathrm{Na}$ tem mestu se je dobro spomniti, kako se je glasilo vprašanje, ki je bilo zastavljeno anketirancem: »Ali (ime ustanove) meni, da je ZNS potreben? Če ja, zakaj? « To je bilo eno 
od dveh glavnih vprašanj ankete, $s$ katerim je avtor želel (vsaj približno) ugotoviti, ali proučevane ustanove ZNS dojemajo kot potreben segment stanovanjskega trga. Avtorju naj bi torej pomagalo konkretneje raziskati, zakaj so oblikovalci politike ZNS ves čas zanemarjali.

Parlamentarni odbor za infrastrukturo in prostor je bil znova zelo kratek: »ZNS bi bil verjetno potreben $\mathrm{v}$ določenem sorazmernem deležu neprofitnega sektorja. « Ta odgovor je problematičen z dveh vidikov. Prvič, beseda »verjetno « nakazuje, da osrednji parlamentarni organ, odgovoren za stanovanjsko politiko, ni prepričan, ali je ZNS potreben ali ne. Drugič, na tej točki ni ustrezno predlagati, da bi morala biti velikost ZNS opredeljena kot določen delež neprofitnega sektorja. Trenutna velikost neprofitnega sektorja (kot je prikazana $\mathrm{v}$ preglednici 1) ne more biti ustrezna podlaga za določitev ustrezne velikosti ZNS. Ta odgovor znova potrjuje, da glavni zakonodajni organ ne kaže resnega zanimanja za obstoj in primerno delovanje ZNS.

Ministrstvo za finance je bilo pri odgovoru na to vprašanje še ravnodušnejše: »Tovrstne zadeve niso v pristojnosti ministrstva za finance.« Glede na podrobnejše razlage, ki jih je isto ministrstvo ponudilo pri odgovorih na nekatera druga zastavljena vprašanja, lahko to izjavo razumemo na dva načina: ali ministrstvo ne ve, ali je ZNS potreben, ali pa mu je za to preprosto vseeno.

Tudi odgovor ministrstva za infrastrukturo in prostor je bil zelo kratek, vendar nekoliko neposrednejši. Njegovo mnenje je, da je učinkovit in pregleden ZNS potreben za omogočanje večjega dostopa do stanovanj, poleg tega pa ta sektor vidi kot segment stanovanjskega sistema, ki bi lahko spodbudil večjo mobilnost prebivalstva. $\mathrm{V}$ primerjavi z odgovori parlamentarnih strank in ministrstva za finance je to pozitivnejše in konstruktivnejše stališče, hkrati pa je še težje razumeti, zakaj ministrstvu, neposredno odgovornemu za oblikovanje stanovanjske politike ter predlaganje ustreznih zakonov in predpisov, do zdaj teh ciljev še ni uspelo doseči.

Podobno kot ministrstvo za infrastrukturo in prostor je tudi večina parlamentarnih strank na to vprašanje odgovorila pritrdilno in jasno. Parlamentarna stranka 1 se je strinjala, da je ZNS potreben kot segment stanovanjske ponudbe, ki bi dopolnjeval ponudbo javnih stanovanj. Parlamentarna stranka 2 je bila bolj empatična, saj naj bi bil ZNS po njenem mnenju hrbtenica najemnega stanovanjskega trga, pri čemer bi morala biti zasebna najemna stanovanja »običajna sestavina naložb zasebnega kapitala, tako domačega kot tujega «. Parlamentarna stranka 4 je bila podobnega mnenja kot parlamentarna stranka 2: strinjala se je, da je ZNS potreben in da mora biti sestavni del slovenskega stanovanjskega trga. Poleg tega bi morali vlad- no poseganje na stanovanjski trg obdržati na čim nižji ravni. Čeprav je to stališče na prvi pogled popolnoma upravičeno, avtor meni, da je treba upoštevati, da stanovanjski trg vsake toliko časa potrebuje različne oblike vladne intervencije za odpravo različnih vrst izkrivljanja trga, ki lahko porušijo ravnotežje med stanovanjsko ponudbo in povpraševanjem. Avtor poudarja, da trenutni položaj v Sloveniji zahteva resne vladne posege v ZNS, preden se lahko doseže deregulacija in omogoči samostojno delovanje stanovanjskega trga.

Čeprav je parlamentarna stranka 3 na to vprašanje odgovorila posredno, lahko njen predlog za izvedbo podrobne predhodne analize stanja na trgu razumemo kot pozitivno in podpirajoče stališče glede obstoja ZNS. Poleg tega je ta stranka izjavila, da je za učinkovito delovanje ZNS treba zagotoviti ustrezno usklajevanje med pristojnimi ministrstvi.

Razen ministrstva za finance (ki je odgovorilo, da za tovrstne zadeve ni pristojno) se vse anketirane ustanove strinjajo, da je ZNS potreben. To je ena od najpomembnejših ugotovitev ankete. Jasno je, da glavne državne ustanove načeloma ne nasprotujejo obstoju tega sektorja in da se oblikovalci politike na splošno strinjajo, da je potreben učinkovit ZNS. Kljub tem novim informacijam pa ostaja dejstvo, da ta sektor dosledno zanemarjajo prav te ustanove, ki imajo ustavna in pravna pooblastila za zagotovitev njegovega normalnega delovanja. Ključno vprašanje je torej še vedno, zakaj je tako. Odgovori na vprašanje, ki je bilo zastavljeno samo parlamentarnim strankam, so predstavljeni v nadaljevanju in lahko v določeni meri nakažejo, $\mathrm{v}$ čem je glavni problem.

\subsection{Vloga državnega zakonodajnega organa}

Kot je bilo že omenjeno, je bilo vprašanje glede potrebe po ZNS eno od dveh glavnih vprašanj ankete. Drugo glavno vprašanje je bilo zastavljeno samo parlamentarnim strankam: $»$ Je (ime parlamentarne stranke) kadar koli obravnavala stanje ZNS in način njegovega delovanja v Sloveniiji? Namen tega vprašanja je bil ugotoviti, katere konkretne dejavnosti so na tem področju izvedli izvoljeni predstavniki državljanov, ki imajo ustavna pooblastila za oblikovanje ter sprejemanje ustrezne stanovanjske zakonodaje in politike.

V odgovoru na to vprašanje je parlamentarni odbor za infrastrukturo in prostor priznal, da med svojim mandatom ( $\mathrm{v}$ času izvajanja ankete je teklo tretje leto njegovega mandata) te teme niti enkrat ni obravnaval. Parlamentarna stranka 1 je pojasnila, da je delovanje ZNS obravnavala samo v okviru razprave o splošnih socialnih in družinskih vprašanjih, parlamentarna stranka 2 pa je izjavila, da namerava to zadevo obravnavati v okviru razprave o novem nacionalnem stanovanjskem programu, ki je bil takrat v pripravi. Parlamentarni stranki 3 in 4 na 
vprašanje nista odgovorili neposredno. Namesto tega sta predlagali seznam ukrepov, ki bi jih želeli vključiti v nov nacionalni stanovanjski program, ki ga je, kot že rečeno, pripravljalo ministrstvo za infrastrukturo in prostor. Ker nista ponudili ustreznega odgovora na zastavljeno vprašanje, lahko sklepamo, da nobena ni obravnavala te teme.

Kot lahko jasno razumemo iz odgovorov na to vprašanje, ni niti ena parlamentarna stranka nikoli konkretno in posebej obravnavala problema delovanja ZNS. Čeprav so bile vse anketirane parlamentarne stranke razmeroma dobro seznanjene s stanjem ZNS, še zlasti z njegovimi pomanjkljivostmi, nobena ni čutila potrebe, da bi o zadevi razpravljala ter parlamentu predlagala (ali vsaj poskušala predlagati) sprejetje ustrezne zakonodaje in primernih ukrepov v okviru stanovanjske politike. To je morda najpomembnejša ugotovitev ankete pri iskanju odgovora na vprašanje, zakaj je bil ta sektor vseskozi zanemarjen in puščn v negotovem položaju.

\subsection{Povzetek odgovorov}

S svojimi odgovori so vse proučevane državne ustanove pokazale, da se zavedajo pomanjkljivosti trenutnega ZNS. Vse priznavajo, da je glede na visoko stopnjo lastniških stanovanj na račun najemnih stanovanj trenutna struktura pravic do posesti stanovanja neustrezna in da nimajo natančnih podatkov o deležu zasebnih najemnih stanovanj. Vse se strinjajo, da način objave podatkov o pravicah do posesti stanovanja ne kaže dejanskega stanja na trgu ter da je število praznih stanovanj, kot je razvidno iz rezultatov popisa, preveliko. Ukrepi, ki jih različne ustanove predlagajo za reševanje tega problema, pa si na splošno popolnoma nasprotujejo. Nekatere podpirajo obdavčitev praznih stanovanj, druge menijo, da bi uvedba ugodnejših fiskalnih ukrepov (ki jo je predlagala večina) spodbudila najemodajalce, da ponudijo svoje nepremičnine na trgu. Avtor meni, da je zadnje učinkovitejši pristop $\mathrm{k}$ reševanju problema. Anketiranci se poleg tega zavedajo, da sodni postopki v Sloveniji trajajo predolgo, kar nekatere potencialne najemodajalce odvrača od vstopa na zasebni najemni trg. Najpomembneje pa je, da se vsi (razen ministrstva za finance, ki ni podalo mnenja o tej zadevi) strinjajo, da je ZNS potreben. Ta ugotovitev pomaga razbliniti vse dvome v glavah tistih, ki jih je nenehno morila pasivna vloga države na tem področju. Poleg tega je treba omeniti, da so proučevane ustanove predlagale številne (večinoma primerne) ukrepe, ki jih je treba izvesti za oblikovanje ustrezne podlage za delovanje ZNS.

$\mathrm{Na}$ splošno so ugotovitve ankete precej spodbudne, kar vsaj raziskovalcem prinaša veliko olajšanje. Hkrati pa je zaradi tega še težje razumeti, zakaj je ZNS še naprej zapostavljen. Glede na izraženo naklonjenost državnih ustanov do tega sektorja je težko razumeti, zakaj te ustanove (vsaka s svojimi pristojnos- tmi na stanovanjskem področju) še niso ukrepale in omogočile normalnega delovanja ZNS. Še vedno ni jasno, zakaj je država - po uvedbi »načela omogočanja «, ki naj bi zagotovilo promocijo, razvoj in normalno delovanje ZNS - popolnoma odpovedala in ni izvedla nobenih ukrepov, ki so bili določeni, da se temu sektorju omogoči, da formalno deluje kot zakonit segment stanovanjskega trga. Avtor v sklepu ponudi razlago, da lahko dejstvo, da država ni priznala pomena ZNS niti zagotovila zakonodajnega ne institucionalnega okvira, potrebnega za njegovo normalno delovanje, pripišemo nenaklonjenosti glavnih ustanov, ki oblikujejo politiko na tem področju.

\section{Sklep}

V prvem delu članka je avtor predstavil dejstvo, da sta bila spodbujanje in razvoj ZNS v Sloveniji ambiciozno predstavljena v okviru nove nacionalne stanovanjske politike, sprejete po uvedbi stanovanjskih reform in pristopa omogočanja. $Z$ novo politiko naj bi država ustvarila pogoje, ki bi spodbudili zasebne naložbe v ZNS in potencialnim najemodajalcem zagotovili ustrezno donosnost naložbe. Vendar pa, kot je bilo opisano v nadaljevanju, država ni uspešno izvedla načela omogočanja, zaradi česar slovenski ZNS še naprej deluje večinoma neformalno, z vsemi neizogibno pripadajočimi negativnimi lastnostmi delovanja na sivem trgu. Preden nadaljujemo razlago o tem, zakaj država ni podprla razvoja tega sektorja, je treba na kratko predstaviti, kaj je bilo pravzaprav bistvo načela »omogočanja «.

Čeprav se je načelo omogočanja po vsej Evropi na široko sprejemalo kot eno od glavnih varčevalnih politik socialne države, so imeli nekateri strokovnjaki pomisleke o njegovem uspešnem izvajanju v praksi. Martyn Pearl (1997: 53) je na primer opozarjal, da »čeprav se pričakuje, da bodo vse lokalne oblasti postale omogočevalci, ni nobene zavezujoče definicije tega, kaj naj bi ta vloga pomenila «. Ian Cole in Barry Goodchild (1995: 53) sta trdila, da je »omogočanje « ambiciozna krilatica, pri kateri gre po njunem mnenju za »... precej izmuzljiv pojem, če ga pobliže pogledamo ... pri čemer ni splošnega dogovora o tem, kakšno obliko bi lahko imel model omogočanja «. Pri obravnavi premika od zagotavljanja k omogočanju $\mathrm{v}$ širšem kontekstu upravljanja na stanovanjskem področju je Robina Goodlad (1993) ugotavljala, da so razprave o procesu preobrazbe lokalnih organov iz najemodajalcev v omogočevalce pogosto preveč poenostavljene. Opozorila je na številne politične kompleksnosti, ki pogosto vplivajo na odnos med javnim in zasebnim sektorjem pri izvajanju stanovanjske politike. Kot je ugotavljal tudi Lennart Lundquist (1991), je zagotavljanje stanovanj dejavnost, ki vključuje zapletene medsebojne povezave med različnimi elementi in akterji na različnih ravneh. $\mathrm{V}$ podrobni raziskavi področja zagotavljanja stanovanj je Peter Ambrose (1991) oblikoval zelo uporaben model, $s$ katerim je 
natančno opredelil vloge, ki jih morajo akterji javnega in zasebnega sektorja imeti na vsaki stopnji »verige zagotavljanja stanovanj«. Najpomembneje pa je, da je vlogo akterjev zasebnega sektorja v tej verigi opisal tako (1991: 95): »Raven njihove dejavnosti in njihov uspeh sta odvisna od pravnega in subvencijskega okvira, v katerem delujejo - torej od vidikov državne stanovanjske politike.« To pomeni, da zasebni sektor vedno deluje v okoljih, ki jih urejajo ter ustrezno nadzirajo zakonodaja in druge relevantne politike, ki jih sprejme država. Konkretno država nadzira in izvaja osnovne mehanizme, ki sprožijo začetne faze celotnega procesa zagotavljanja stanovanj. Ključno vlogo države poudarja tudi Michael Oxley (2004: 8): »Stanovanjski in zemljiški trgi ne obstajajo brez navad, zakonov in konvencij, ki jih določajo družbeni in politični procesi. Trgi ne obstajajo neodvisno od države in vlad. « Na tej teoretični podlagi torej lahko sklepamo, da je stanje ZNS Sloveniji neposredna in logična posledica nedejavnosti države, ki v verigi zagotavljanja stanovanj ni opravila svoje » vloge omogočanja «.

Hkrati avtor ugotavlja, da so ključne ustanove, ki so sodelovale $\mathrm{v}$ anketi, na splošno naklonjene formalnemu in normalnemu delovanju ZNS (čeprav se njihovi pogledi razlikujejo). Zakaj torej to splošno soglasje ni bilo uresničeno tudi v praksi? Glede na to, da sektor ni prejel podpore nobene od različnih zaporednih vlad, ki so bile na oblasti od uvedbe stanovanjskih reform, se avtor nagiba $\mathrm{k}$ razlagi, da je za trenutno stanje preprosto kriva nenaklonjenost ključnih državnih ustanov do tega sektorja. Med različnimi odgovori anketiranih ustanov lahko strnemo nekatera stališča, ki so po avtorjevem mnenju lahko prispevala $\mathrm{k}$ trenutnemu stanju.

- Stališč 1: Parlamentarni odbor za infrastrukturo in prostor se ni mogel jasno opredeliti, ali bi podprl sprejetje politike, ki bi bila namenjena krepitvi ZNS in bi se tako razlikovala od politike, ki je bila v preteklosti skoraj v celoti naklonjena le povečanju deleža lastniških stanovanj.

- Stališč 2: Odgovori ministrstva za finance na splošno kažejo, da ZNS in celotna razprava o tej temi zanj nista pomembna. Ker vidi ZNS kot segment, ki ne pomeni potencialnega vira prihodkov v državni proračun, njegovi odgovori kažejo, da mu ni preveč mar za to, ali ZNS obstaja ali ne. Treba je poudariti, da je vloga tega ministrstva pri oblikovanju formalnega ZNS ključna, saj bi moralo to (znotraj vlade) odobriti vse fiskalne ukrepe za oblikovanje primernega gospodarskega okolja in zagotovitev državne podpore, potrebne za uspešno delovanje tega sektorja.

- Stališče 3: Parlamentarni odbor za infrastrukturo in prostor je odkrito priznal, da ni seznanjen $s$ trenutnim načinom delovanja ZNS. To priznanje torej kaže, da se zakonodajni organ, neposredno odgovoren za stanovanjska vprašanja, ni niti malo potrudil, da bi ugotovil, kaj se dogaja z ZNS.
- Stališče 4: Parlamentarni odbor za infrastrukturo in prostor je izjavil, da bi bil ZNS »verjetno potreben « kot določen delež neprofitnega sektorja. Ta predlog je težko resno obravnavati, glede na to, da se že velikost neprofitnega sektorja vztrajno zmanjšuje.

- Stališč 5: Odgovori parlamentarnih strank so najzgovornejši. Kljub neprepričljivim poskusom anketiranih parlamentarnih strank, da bi pustile vtis, da so se s temi vprašanji ukvarjale, njihovi odgovori jasno kažejo, da ZNS nobena od njih ni namenila večje pozornosti. Če bi jo, bi njihovi ukrepi nazadnje povzročili določene konkretne in vidne izboljšave.

Dejstvo, da odgovorne državne ustanove niso izvedle ukrepov, ki bi povzročili pozitivne spremembe v ZNS, kaže, da se ne zavedajo popolnoma pozitivne vloge, ki bi jo ta lahko imel kot alternativa stanovanjskemu lastništvu. Na poglede in stališča politikov glede ZNS lahko torej vplivajo tudi drugi kompleksni ideološki dejavniki. Avtor priznava, da še vedno nima dokončnih odgovorov na zastavljena vprašanja. Oblikovalci politike morda preprosto ne želijo oblikovati in podpreti učinkovitega ZNS, morda država namerno izvaja politiko, katere cilj je čim večji delež lastniških stanovanj. Zato bi se morda v naslednji raziskavi tega področja namesto na stališča glede ZNS bilo bolje osredotočiti na proučevanje stališč oblikovalcev politike glede lastniških stanovanj.

\section{Richard Sendi}

Urbanistični inštitut Republike Slovenije, Ljubljana, Slovenija

E-pošta: richard.sendi@uirs.si

\section{Zahvala}

Avtor se zahvaljuje Agenciji za raziskovalno dejavnost Republike Slovenije, ki je financirala triletni raziskovalni projekt, katerega del ugotovitev je predstavljen in obravnavan $v$ tem članku.

\section{Opombe}

[1] Priprava nove nacionalne stanovanjske politike je bila predvidena s Stanovanjskim zakonom iz leta 1991, vendar je vlada prvi osnutek nacionalne stanovanjske politike odobrila ter poslala $v$ obravnavo in končno sprejetje parlamentu šele leta 1995. Iz neznanih razlogov je državni zbor končno različico nacionalnega stanovanjskega programa sprejel šele leta 2000. V vmesnem obdobju se je kot uradni veljavni dokument stanovanjske politike uporabljal osnutek iz leta 1995 (čeprav ga parlament še ni sprejel).

${ }^{[2]} \mathrm{V}$ času izvajanja ankete je bilo $v$ državnem zboru sedem političnih strank. Ker so nekatere pozneje spremenile ime ali so po naslednjih parlamentarnih volitvah zaradi nezadostnega števila prejetih glasov prenehale obstajati, so $v$ tej razpravi imenovane "parlamentarna stranka 1«, "parlamentarna stranka 2« itd.

${ }^{[3]}$ Vprašalnik je bil poslan različnim državnim ustanovam še pred izdajo publikacije Statističnega urada Republike Slovenije iz leta 2013, ki je na avtorjevo zahtevo prvič vsebovala tudi podatke o fondu najemnih stanovanj $v$ zasebni lasti. 


\section{Viri in literatura}

Ambrose, P. (1991): The housing provision chain as a comparative analytical framework. Scandinavian Housing and Planning Research, 8(2), str. 91-104. DOI: 10.1080/02815739108730263

Ambrose, P. (1992): The performance of national housing systems: A three-nation comparison. Housing Studies, 7(3), str. 163-176. DOI: 10.1080/02673039208720733

Balchin, P. (ur.) (1996): Housing policy in Europe. London, Routledge.

Boelhouwer, P. (2002): Trends in Dutch housing policy and the shifting position of the social rented sector. Urban Studies 39(2), str. 219-236. DOI: $10.1080 / 00420980120102939$

Boelhouwer, P., in van der Heijden, H. (1992): Housing systems in Europe: Part 1. A comparative study of housing policy. Delft, Delft University Press.

Boelhouwer, P., in van der Heijden, H. (1996): The private rental sector in Western Europe. Housing Studies, 11(1), str. 13-33.

DOI: $10.1080 / 02673039608720843$

Cole, I., in Furbey, R. (1994): The eclipse of council housing. London, Routledge.

Cole, I., in Goodchild, B. (1995): Local housing strategies in England: An assessment of their changing role and content. Policy and Politics, 23(1), str. 49-60. DOI: 10.1332/030557395782227348

Crook, A. D. H., in Kemp, P. A. (1996): The revival of private rented hou sing in Britain. Housing Studies 11(1), str. 51-68.

DOI: $0.1080 / 02673039608720845$

Crook, T., in Kemp, P. A. (ur.) (2014): Private rental housing. Comparative perspectives. Cheltenham, Edward Elgar.

De Decker, P., in Dewilde, C. (2010): Home-ownership and asset-based welfare: The case of Belgium. Journal of Housing and the Built Environment, 25, str. 243-262. DOI: 10.1007/s10901-010-9185-6

Dieleman, F., in Everaers, P. C. J. (1994): From renting to owning: Life course and housing market circumstances. Housing Studies, 9(1), str. 11-25. DOI: 10.1080/02673039408720772

Dol, K., in Haffner, M. (ur.) (2010): Housing statistics in the European Union 2010. Delft, OTB Research Institute for the Built Environment.

Doling, J., in Ronald, R. (2010): Property-based welfare and European homeowners: How would housing perform as a pension? Journal of Housing and the Built Environment, 25, str. 227-241.

DOI: $10.1007 /$ s10901-010-9184-7

Donner, C. (2006): Housing policies in Central Eastern Europe. Dunaj, Christian Donner.

Elsinga, M., in Hoekstra, J. (2005): Homeownership and housing satisfaction. Journal of Housing and the Built Environment, 20(4), str. 401-424. DOI: 10.1007/s10901-005-9023-4

Erdösi, S., Hegedüs, J., in Somogyi, E. (2000): Is private rental an option for urban housing provision in Hungary? Journal of Housing and the Built Environment, 15(3), str. 267-291. DOI: 10.1023/A:1010137519113

Forrest, R., in Murie, A. (ur.) (1991): Selling the welfare state. The privatisation of public housing. London, Routledge.

Forrest, R., in Murie, A. (ur.) (1995): Housing and family wealth - comparative international perspectives. London, Routledge.

Goodlad, R. (1993): The housing authority as enabler. Coventry, Institute of Housing and Longman.

Gray, P., in McAnulty, U. (2008): The increased role of the private rented sector in catering for low-income groups in Northern Ireland. European
Journal of Housing Policy, 8(4), str. 361-377. DOI: 10.1080/14616710802449588

Gruis, V., Tsenkova, S., in Nieboer, N. (2009): Management of privatised housing. International policies and practice. Chichester, Wiley-Blackwell.

Harloe, M. (1985): Private rented housing in the United States and Europe. London, Croom Helm.

Hulse, K., in Pawson, H. (2010): Worlds apart? Lower-income households and private renting in Australia and the UK. International Journal of Housing Policy, 10(4), str. 399-419. DOI: 10.1080/14616718.2010.526403

Karn, V., in Nyström, L. (1998): The control and promotion of quality in new housing design. V: Kleinman, M., Matznetter, W., in Stephens, M. (ur.): European integration and housing policy, str. 125-154. London, Routledge.

Kemp, P. A. (1987): Some aspects of housing consumption in late nineteenth century England and Wales, Housing Studies, 2(2), str. 1-16. DOI: 10.1080/02673038708720585

Kemp, P. A. (2011): Low-income tenants in the private rental housing market. Housing Studies, 26(7-8), str. 1019-1034. DOI: 10.1080/02673037.2011.615155

Kemp, P. A. (2015): Private renting after the global financial crisis. Housing Studies, 30(4), str. 601-620. DOI: 10.1080/02673037.2015.1027671

Kemp, P. A., in Kofner, S. (2010): Contrasting varieties of private renting: England and Germany. International Journal of Housing Policy, 10(4), str. 379-398. DOI: 10.1080/14616718.2010.526401

Kemp, R. L. (ur.) (1991): Privatization. The provision of public services by the private sector. London, McFarland \& Company.

Kleinhans, R., in Elsinga, M. (2010): "Buy your home and feel in control": Does homeownership achieve the empowerment of former tenants of social housing? International Journal of Housing Policy, 10(1), str. 41-61. DOI: 10.1080/14616710903573757

Kristensen, H. (2002): Social housing policy and the welfare state: A Danish perspective. Urban Studies 39(2), str. 255-263. DOI: 10.1080/00420980120102957

Lundquist, L. J. (1991): Rolling stones for the resurrection of policy as the focus of comparative housing research. Scandinavian Housing and Planning Research, 8(2), str. 79-90. DOI: 10.1080/02815739108730262

Lux, M., in Mikeszova, M. (2012): Property restitution and private rental housing in transition: The case of the Czech Republic. Housing Studies, 27(1), str. 77-96. DOI: 10.1080/02673037.2012.629643

Lux, M., in Sunega, P. (2010): Private rental housing in the Czech Republic: Growth and . . . ? Czech Sociological Review, 46(3), str. 349-373. DOI: $10.1080 / 02673037.2012 .629643$

Malpass, P. (ur.) (1997): Ownership, control and accountability: The new governance of housing. Coventry, The Chartered Institute of Housing.

Malpass, P., in Means, R. (ur.) (1993): Implementing housing policy. Buckingham, Open University Press.

Mandič, S. (2000): Trends in central eastern European rented sectors. Journal of Housing and the Built Environment, 15(3), str. 217-231. DOI: 10.1023/A:1010109920039

Mandič, S., in Filipovič Hrast, M. (2015): Alternative socialnemu stanovanju: pogledi prosilcev o različnih možnostih. Urbani izziv, 26(1), str. 5-16. DOI: 10.5379/urbani-izziv-2015-26-01-001

Matznetter, W. (2002): Social housing policy in a conservative welfare state: Austria as an example. Urban Studies 39(2), str. 265-282. DOI: 10.1080/00420980120102966

Monk, S., in Whitehead, C. (ur.) (2000): Restructuring housing systems. York, Publishing Services Ltd. York. 
Nacionalni stanovanjski program (Npsta). Uradni list Republike Slovenije, št. 43/2000. Ljubljana.

Oxley, M. (2004): Economics, planning and housing. New York, Palgrave Macmillan.

Pareja Eastaway, M., in Varo, I. S. M. (2002): The tenure imbalance in Spain: The need for social housing policy. Urban Studies 39(2), str. 283295. DOI: 10.1080/00420980120102975

Pearl, M. (1997): Social housing management. A critical appraisal of housing practice. London, Macmillan.

Priemus, H., in Dieleman, F. (2002): Social housing policy in the European Union: Past, present and perspectives. Urban Studies 39(2), str. 191200. DOI: $10.1080 / 00420980120102911$

Priemus, H., in Mandič, S. (2000): Rental housing in central and eastern Europe as no man's land. Journal of Housing and the Built Environment, 15(3), str. 205-215. DOI: 10.1023/A:1010186618204

Ridley, N. (1988): The local right: Enabling not providing. London, Centre for Policy Studies.

Rossi, P. H., in Weber, E. (1996): The social benefits of home ownership: Empirical evidence from national surveys. Housing Policy Debate, $7(1)$, str. 1-35. DOI: 10.1080/10511482.1996.9521212

Ruonavaara, H. (1990): Four models of explaining the growth of home-ownership. Scandinavian Housing \& Planning Research, 7, str. 129-142. DOI: $10.1080 / 02815739008730228$

Scanlon, K., in Kochan, B. (2011): Towards a sustainable private rented sector. The lessons from other countries. London, The London School of Economics and Political Sciences.

Sendi, R. (1995): Housing reform and housing conflict: The privatisation and denationalisation of public housing in the Republic of Slovenia in practice. International Journal of Urban and Regional Research, 19(3), str. 435-446. DOI: 10.1111/j.1468-2427.1995.tb00519.x

Sendi, R. (1999): Private rented housing in Slovenia: A non-existent housing sector? Netherlands Journal of Housing and the Built Environment 14(3), str. 309-322. DOI: 10.1007/BF02496684

Sendi, R., Mandič, S., Filipovič, M., in Cirman, A. (2007): Stanovanjska reforma: pričakovanja, potrebe, realizacija. Ljubljana, Urbani izziv - publikacije.

Stamso, M. N. (2008): Grants for first-time homeowners in Norway - Distributional effects under different market and political conditions. International Journal of Housing Policy, 8(4), str. 379-397.

DOI: $10.1080 / 14616710802449703$

Statistični urad Republike Slovenije (2012): Census report: People, families, housing. Ljubljana.

Struyk, R. J. (ur.) (1996): Economic restructuring of the former Soviet Bloc. The case of housing. Washington, DC, The Urban Institute Press.

Telgarsky, J. P., in Struyk, R. J. (1990): Toward a market-oriented housing sector in Eastern Europe. Developments in Bulgaria, Czechoslovakia, Hungary, Poland, Romania, and Yugoslavia. Urban Institute Report 90-10. Washington, The Urban Institute Press.

Toussaint, J. (2011): Housing assets as a potential solution for financial hardship: Household's mental accounts of housing wealth in three European countries. Housing, Theory and Society, 28(4), str. 320-341. DOI: 10.1080/14036096.2011.554853

Tsenkova, S. (2009): Housing policy reforms in post-socialist Europe. Lost in transition. Heidelberg, Pysica-Verlag. DOI: 10.1007/978-3-7908-2115-4

Turner, B., Hegedüs, J., in Tosics, I. (ur.) (1992): The reform of housing in Eastern Europe and the Soviet Union. New York, Routledge.
Turner, B., in Whitehead, C. M. E. (2002): Reducing housing subsidy: Swedish housing policy in an international context. Urban Studies 39(2), str. 201-217. DOI: 10.1080/00420980120102920

United Nations Centre for Human Settlements (1992): Global strategy for shelter to the year 2000. Nairobi. 